\title{
A küszöbvektor hatása a megkülönböztethetôségre a növényfajták DUS vizsgálatában
}

\author{
HARANGOZÓ TAMÁS-VERESS ZOLTÁN \\ Mezôgazdasági Szakigazgatási Hivatal, Központ, Budapest
}

\section{Összefoglalás}

A növényfajták állami elismerésének és oltalmazásának egyik feltétele az eredményes DUS vizsgálat, melynek egyik lényeges eleme a megkülönböztethetőségi (Distinctness) vizsgálat. A megkülönböztethetőség a morfológiai tulajdonságok kifejezôdési fokozataiban rejlő különbségen alapul, melyet egy adott küszöbértékhez viszonyítunk. A küszöbérték (d'x) megválasztása alapvetôen meghatározza a fajták megkülönböztethetôségét.

Elemzésünkben homogén és heterogén küszöbvektort alkotó küszöbértékek változtatásának megkülönböztethetőségre gyakorolt hatását vizsgáltuk martonvásári és szegedi nemesítésú őszi búza fajták 2006. évi DUS fajtaleírás mátrixát felhasználva. A fajták páros összehasonlításával vizsgáltuk a megkülönböztethetôségi küszöbvektor (D’x), illetve az azt alkotó küszöbértékek (d'x) és a megkülönböztethetô fajták viszonyát. A homogén küszöbvektorokkal kapcsolatban megállapítottuk, hogy a d'x = 3 küszöbérték választása eredményez kezelhetô mértékú megkülönböztethetô, illetve nem megkülönböztethető fajtapár arányt. A két fajtacsoport közötti nem megkülönböztethetố fajtapár különbség matematikailag igazolható.

A heterogén küszöbvektorok esetében a d'x = 3 küszöbértéket tulajdonságonként egy értékkel csökkentve és növelve láthatóvá váltak azok a tulajdonságok közötti különbségek, melyek jelentős hatást gyakoroltak a megkülönböztethetőségre. A küszöbvektor változtatásának hatása alapján a tulajdonságokat 5 csoportba soroltuk. A DUS vizsgálatok során a megkülönböztethetôség megállapítására felhasznált küszöbvektorok alkalmasak a különböző fajtacsoportok közötti morfológiai különbségek feltárására is.

Kulcsszavak: ôszi búza, DUS, megkülönböztethetôség, küszöbvektor, küszöbérték 


\title{
Effect of threshold vector on the distinctness in the DUS testing of plant varieties
}

\author{
T. HARANGOZÓ-Z. VERESS \\ Central Agricultural Office, Budapest
}

\begin{abstract}
Summary
Positive DUS test is a prerequisite of national listing and plant breeder's right. Assessment of Distinctness is the key element of the DUS testing. Distinctness is based on the difference in state of expression of morphological characteristics related to a fixed threshold value. Setting of the threshold value (d'x) fundamentaly defines distinctness.

The effect of homogeneous and heterogeneous threshold vectors on distinctness was studied by using 2006. DUS variety description matrices of winter wheat varieties bred in Szeged and Martonvásár. The relation of the threshold vector (D'x) and its (d'x) threshold value components and the number of distinct varieties was revealed by pairwise comparison. Concerning homogeneous threshold vectors authors found that setting threshold values at $\mathrm{d}^{\prime} \mathrm{x}=3$ resulted manageable proportion of distinct and non-distinct pairs. The difference of non-distinct variety pairs between the two variety groups was mathematically justified.

In case of heterogeneous threshold vectors one value decrease and increase of d'x $=3$ threshold values at each trait revealed the differences affecting significantly distinctness. Characteristics were divided into 5 groups according to their reaction to threshold value modification. Threshold vectors applied in DUS tests to declare distinctness are available to reveal morphological differences between groups of varieties.
\end{abstract}

Key words: winter wheat, DUS, distinctness, threshold vector, threshold value

\section{Bevezetés}

A növényfajták DUS vizsgálata során a megkülönböztethetőséget a vizsgálati irányelvben meghatározott tulajdonságok kifejeződési fokozatainak értékelésével állapítjuk meg. A megkülönböztethetőség fogalmi meghatározása a hasonlóságnál egyszerúbbnek tûnik, mivel az előbbi a gyakorlatban könnyebben számszerúsíthetô. Az 1991. évi UPOV (Union for the Protection of New Plant Varieties) Egyezmény még elég általánosan fogalmaz a megkülönböztethetőség vonatkozásában. A törvénybe iktatott magyar fordítás alapján megkülön- 
böztethető a fajta, ha határozottan eltér (clearly distinguishable) bármely más, a bejelentés napján már közismert fajtáktól.

Az EU Közösségi Fajtahivatal (CPVO) által kiadott TP003/4 ószi búza DUS vizsgálati irányelv (CPVO TP003/4 2008) - Protocol for Distinctness, Uniformity and Stability Tests - szerint a bonitált tulajdonságoknál az egyértelmú megkülönböztethetôség feltétele, hogy a kifejezôdési fokozatok legalább egy tulajdonságnál, legalább egy értékkel térjenek el egymástól.

Az UPOV Fajtavizsgálati Kézikönyv megkülönböztethetôség megállapításával foglalkozó része (UPOV TGP/9 2002) már felveti annak lehetôségét, hogy a mennyiségi tulajdonságoknál a környezeti tényezők változékonysága miatt az egyértelmú megkülönböztethetôséghez szükség lehet nagyobb különbségre is, mint két kifejezôdési fokozat. A tényleges döntésekben azonban a megkülönböztethetőség ennél összetettebb elv szerint kerül megállapításra. Mivel megkülönböztethetőséghez többnyire nem csak egy, hanem például a mért tulajdonságok ordinált változatra transzformált alakjánál többfokozatos különbségre van szükség az egyértelmú megkülönböztethetôséghez, ezért a tulajdonságokhoz azoknak típusa alapján egyenként kell a küszöbértéket megállapítani.

Az eltérés mértékének számszerû megállapítása érdekében került bevezetésre a bonitálási küszöb és megkülönböztethetőségi küszöbszázalék (Csapó és Veress 1997). Jelenlegi gyakorlat szerint, ha két fajta bármely tulajdonságának kifejeződési fokozata közti különbség (dx) meghaladja az előre meghatározott megkülönböztethetôségi küszöbértéket (d'x), akkor a két fajtát egymástól megkülönböztethetônek tekintjük. A megkülönböztethetőség megállapításának alapvetô feltétele éppen az a küszöbérték, melynek megválasztása alapvetôen meghatározza a megkülönböztethetőséget.

További finomítást jelent, ha a megkülönböztethetőség a tulajdonságonkénti kifejeződési fokozat különbséghez rendelt súlyértékek összegezésével kapott érték, illetve egy előre meghatározott kritikus küszöbérték viszonyától függ (Veress 1999).

Két fajta $\mathrm{D}_{\text {táv }}$ távolságán az adott kifejezôdési fokozatok különbségei összegének a lehetséges maximális különbség összeghez való viszonyát értjük. A d'x értéknek a megkülönböztethetôségi küszöbértéket definiáltuk (Harangozó et al. 2007).

A DUS vizsgálatban szereplő fajták, tulajdonságok általános vizsgálatának egyik módszerét képezi a megkülönböztethetőségi százalék módszer (Veress és Lázár 1997). E módszernél a küszöbértékek változtatásával vizsgálták a tulajdonságokat és szerepüket a megkülönböztethetôségben. A módszer alkalmazásával 
a megkülönböztethetőséget először az ôszi búza, ôszi árpa és cirok fajoknál értékelték Garzó et al. (1997), akik a küszöbérték megválasztását a tulajdonság kifejezôdésének környezeti stabilitásához kötötték. A megkülönböztethetőségi százalék módszer segítségével a tulajdonságok tipizálására is történt kísérlet (Lázár et al. 1998). A megkülönböztethetőségi százalék módszer továbbfejlesztése jelenleg is folyik. Az MgSzH jogelődje által kiadott belsô használatra összeállított DUS Vizsgálati Módszertani Kézikönyv (Országos Mezőgazdasági Minôsítô Intézet, 1996) a d'x megkülönböztethetőségi küszöbértéket tulajdonságonkénti bontásban minimum távolság néven adja meg. A megkülönböztethetôségi küszöbértéket a bonitált tulajdonságok esetén egyszerúen lehet alkalmazni, mért adatok esetén a megválasztása előzetes vizsgálatokat igényel.

A megkülönböztethetőséghez általában elegendő, ha egy tulajdonságnál egyértelmú a különbség. Elôfordulhat azonban, hogy a kifejezôdési fokozatok közti különbség nehezen értékelhetô, ezért a metodikai szakirodalom a distinctness plus fogalmat is bevezette (UPOV TWC 21/4 2003). A megközelítés lényege, hogy a tulajdonságok súlyozásával érheti el egy fajta a kritikus megkülönböztethetôségi szintet. Ebben az esetben több DUS tulajdonság a saját részeredményével együttesen járul hozzá a megkülönböztethetôséghez. Erre az elvre épül az általunk kifejlesztett és használt program vagy a francia fejlesztésú GAIA szoftver is.

A D'x küszöbvektort alkotó d'x küszöbértékek csökkentése vagy növelése az adott tulajdonságoknál jelentős hatást is gyakorolhat a megkülönböztethetôségre. Elemzésünkben arra a kérdésre kerestünk választ, hogy az ószi búza DUS vizsgálata során a mennyiségi jellegú tulajdonságokhoz rendelt d’x küszöbértékek hogyan befolyásolják a megkülönböztethetőséget. Munkánkban két 50 elemú ôszi búza fajtaleírás mátrix segítségével a d'x küszöbérték változtatásának hatását vizsgáltuk a nem megkülönböztethető fajtapárok számának és arányának elemzésével. A küszöbérték változtatásának a megkülönböztethetôségre gyakorolt hatása alapján a tulajdonságokból csoportokat tudtunk képezni.

\section{Anyag és módszer}

A DUS vizsgálat során alkalmazott küszöbvektorokat két, egyenként 50 fajtás őszi búza DUS fajtaleírás mátrix segítségével elemeztük. A fajtaleírások az MgSzH Tordasi Fajtakísérleti állomásán 2006. évben végzett DUS vizsgálatokból származtak. Az egyik adatállomány az MTA Martonvásári Kutatóintézet által nemesített fajtákból, a másik pedig a Szegedi Gabonakutató KHT által nemesített fajtákból állt. A megkülönböztethetôséget csak azon tulajdonságok 
figyelembevételével állapítottuk meg, amelyeknél a kifejeződési fokozat értékek az irányelv szerint 1-9 között változhattak. Az ôszi búza esetében 20 ilyen tulajdonság található (1. táblázat). A 11., 14., 16., 23. és 25. sorszámú DUS tulajdonságok az értékelésben nem szerepeltek, mert nem mennyiségi jellegúek. A 20 tulajdonsághoz tartozó d'x megkülönböztethetőségi küszöbérték együttesen egy D'x küszöbvektort alkot. Ha a D'x küszöbvektor csak egyféle d'x értékből áll, akkor a küszöbvektor homogénnek, ha többféle értékből áll, akkor heterogénnek neveztük (2. táblázat). Heterogén küszöbvektoroknak munkánkban csak azon típusaival foglalkoztunk, melyek kétféle értéket tartalmaztak. A fajták páros összehasonlítása során egy $(i, j)$ fajtapárt akkor tekintettük egy-

mástól megkülönböztethetőnek, ha legalább egy tulajdonság esetén $\left|\mathrm{d} x_{\mathrm{i}}-\mathrm{d} \mathrm{x}_{\mathrm{j}}\right| \geq \mathrm{d}$ 'x, ahol dx adott tulajdonságra jellemzô kifejezôdési fokozat érték (ez a megkülönböztethetôség nem súlyozott változata). A nem megkülönböztethető fajtapárokat NMF rövidítéssel jelöltük. Mivel a gyakorlati ôszi búza fajtavizsgálat a d'x = 3 küszöbértéket alkalmazza, ezért elemzésünkben is ezt tekintettük kiindulási állapotnak.

A megkülönböztethetóséget az összes lehetséges (1225 db) fajtapár figyelembevételével az általunk kifejlesztett, Visual Basic nyelven írt program futtatásával állapítottuk meg.

\section{Eredmények ismertetése és értékelése}

\section{Homogén D’x küszöbvektorok vizsgálata}

A megkülönböztethetôség megállapítását D’x = 1-7 közötti küszöbvektorokkal végeztük el. A küszöbvektoronkénti NMF arányokat és a nem megkülönböztethetô fajták számát a 3. táblázat mutatja be.

A D'x = 1 és D'x = 2 küszöbvektor esetén gyakorlatilag minden fajtapár megkülönböztethető (NMF = 0\%). D'x =3 küszöbvektor esetén jelentkeztek először a NMF-ok. D'x $=3$ és D'x $=4$ esetén mindkét fajtakörnél a NMF arány megfelelö. A D'x $=7$ esetén a fajtapárok 72\%-a már nem megkülönböztethetô. Azonban, ha a fajtapárok mellett a nem megkülönböztethető fajták számát is figyelembe vesszük, akkor a D'x = 4 esetében a fajtaszámban bekövetkezố ugrás olyan nagy mértékú - 15-rôl 43 db-ra a GK fajtánál, illetve 24-rôl 43 db-ra az MV fajtáknál -, hogy a d'x = 4 küszöbértékek gyakorlati alkalmazása szinte lehetetlen. A táblázat utolsó sorában szereplő D'x = 7 küszöbvektor esetén a 942 db NMF-ban (72\%) már mind az 50 fajta valamely párkombinációban szerepelt, így a fennmaradó 283 db megkülönböztethetô fajtapárban már újabb fajta nem vett részt. 
1. táblázat. A vizsgált DUS tulajdonságok osztályba sorolása a küszöbérték változtatás érzékenysége alapján GK és MV fajtáknál

\begin{tabular}{|c|c|c|c|c|c|}
\hline DUS tulajdonság & $\begin{array}{l}\text { Típus } \\
\text { (2) } \\
\text { GK } \\
\end{array}$ & $\begin{array}{l}\text { Típus } \\
\text { (2) } \\
\text { MV } \\
\end{array}$ & $\underset{(1)}{\text { DUS tulajdonság }}$ & $\begin{array}{c}\text { Típus } \\
\text { (2) } \\
\text { GK } \\
\end{array}$ & $\begin{array}{l}\text { Típus } \\
\text { (2) } \\
\text { MV }\end{array}$ \\
\hline $\begin{array}{l}{[1] * \text { csíra }} \\
\text { antociánossága (3) }\end{array}$ & B & B & $\begin{array}{l}{[12]^{*} \text { kalász }} \\
\text { tömöttsége (13) }\end{array}$ & B & A \\
\hline $\begin{array}{l}{[2]^{*} \text { növekedési }} \\
\text { típus (4) }\end{array}$ & B & B & $\begin{array}{l}{[13]^{*} \text { kalász hossza }} \\
\text { (14) }\end{array}$ & C & B \\
\hline $\begin{array}{l}\text { [3] visszzahajló } \\
\text { zászlós levelú } \\
\text { növények } \\
\text { gyakorisága (5) }\end{array}$ & C & C & $\begin{array}{l}{[15]^{*} \text { szálka / }} \\
\text { szálka csonk } \\
\text { hossza (15) }\end{array}$ & $\mathrm{E}$ & B \\
\hline $\begin{array}{l}{[4]^{*} \text { kalászolás ideje }} \\
(6)\end{array}$ & C & C & $\begin{array}{l}{[17]^{*} \text { legfelsô }} \\
\text { orsótag konvex } \\
\text { oldal szôrözött- } \\
\text { sége (16) }\end{array}$ & C & $\mathrm{D}$ \\
\hline $\begin{array}{l}{[5]^{*} \text { levélhüvely }} \\
\text { viaszossága (7) }\end{array}$ & B & B & $\begin{array}{l}\text { [18]* kalászka- } \\
\text { pelyva váll- } \\
\text { szélessége (17) }\end{array}$ & C & C \\
\hline $\begin{array}{l}{[6]^{*} \text { levéllemez }} \\
\text { viaszossága (8) }\end{array}$ & B & B & $\begin{array}{l}{[19]^{*} \text { kalászka- }} \\
\text { pelyva vállalakja } \\
\text { (18) }\end{array}$ & C & B \\
\hline $\begin{array}{l}{[7] * \text { kalász }} \\
\text { viaszossága (9) }\end{array}$ & D & C & $\begin{array}{l}{[20]^{*} \text { kalászka- }} \\
\text { pelyva foghossza } \\
\text { (19) }\end{array}$ & $\mathrm{E}$ & C \\
\hline $\begin{array}{l}{[8]^{*} \text { kalásztartó }} \\
\text { szártag viaszosság } \\
(10)\end{array}$ & $\mathrm{D}$ & B & $\begin{array}{l}{[21]^{*} \text { kalászka- }} \\
\text { pelyva fogalakja } \\
(20)\end{array}$ & B & C \\
\hline $\begin{array}{l}{[9]^{*} \text { növény }} \\
\text { magasság (11) }\end{array}$ & B & B & $\begin{array}{l}{[22]^{*} \text { kalászka- }} \\
\text { pelyva belsố } \\
\text { szốrözöttség (21) }\end{array}$ & B & B \\
\hline $\begin{array}{l}{[10]^{*} \text { szalmaszár }} \\
\text { bélvastagsága (12) }\end{array}$ & B & $\mathrm{C}$ & $\begin{array}{l}{[24]^{*} \text { szem fenolos }} \\
\text { elszínezôdése }(22)\end{array}$ & $\mathrm{E}$ & C \\
\hline
\end{tabular}

* zárójelben a CPVO protokoll szerinti tulajdonság sorszám [ ${ }^{*} \mathrm{Nr}$. of DUS characteristic in CPVO protocol in brackets]

Table 1. Classification of DUS characteristics on the basis of their sensitivity to change threshold value. (1) DUS characteristic, (2) Type, (3) Antocyanid content of embryo, (4) Growth type, (5) Frequency of reclinate plants with bannered leaves, (6) Time of earing, (7) Wax content of leaf sheath, (8) Wax content of leaf blade, (9) Wax content of ear, (10) Wax content of ear-holding internode, (11) Plant height, (12) Internal thickness of culm, (13) Thickness of ear, (14) Lenght of ear, (15) Lenght of spikelet/spikelet stumb, (16) Hairs of the convex side of the highest spindle part, (17) Width of ear husk shoulder, (18) Shape of ear husk shoulder, (19) Lenght of ear husk dent, (20) Shape of ear husk dent, (21) Internal hairs of ear husk, (22) Phenol discolourisation of the grain. 
2. táblázat. Példa a homogén és heterogén D’x küszöbvektor értékekre

\begin{tabular}{|c|c|c|c|c|}
\hline \multicolumn{2}{|c|}{$\begin{array}{l}\text { DUS tulajdonság } \\
\text { (1) }\end{array}$} & \multicolumn{2}{|c|}{$\begin{array}{c}\text { Homogén D'x } \\
\text { küszöbvektor (2) }\end{array}$} & $\begin{array}{c}\text { Heterogén D'x } \\
\text { küszöbvektor (3) }\end{array}$ \\
\hline \multicolumn{2}{|c|}{ [4]* kalászolás ideje (4) } & \multicolumn{2}{|c|}{3} & 3 \\
\hline \multicolumn{2}{|c|}{ [5]* levélhüvely viaszossága (5) } & \multicolumn{2}{|l|}{3} & 3 \\
\hline \multicolumn{2}{|c|}{ [6]* levéllemez viaszossága (6) } & \multicolumn{2}{|l|}{3} & 3 \\
\hline [7]* kalász vias & zossága (7) & \multicolumn{2}{|l|}{3} & 4 \\
\hline \multicolumn{2}{|c|}{$\begin{array}{l}{[8]^{*} \text { kalásztartó szártag }} \\
\text { viaszossága (8) }\end{array}$} & \multicolumn{2}{|l|}{3} & 4 \\
\hline \multicolumn{5}{|c|}{$\begin{array}{l}\text { * zárójelben a CPVO protokol szerinti sorszám [* Nr. of DUS characteristic in CPVO protocol in } \\
\text { braclets] } \\
\text { Table 2. Example for homogeneous and heterogeneous threshold vector. (1) DUS characteristics } \\
\text { (2) Homogeneous threshold vector, (3) Heterogeneous threshold vector, (4) Earing time, (5)Wax } \\
\text { cover of leaf sheath, (6) Wax cover of leaf blade, (7) Wax cover of ear, (8) Wax cover of ear-holding } \\
\text { internode. }\end{array}$} \\
\hline \multicolumn{5}{|c|}{$\begin{array}{l}\text { 3. táblázat. A NMF száma és aránya a GK és MV fajtáknál Dx =1-7 küszöbvektor } \\
\text { alkalmazása esetén }\end{array}$} \\
\hline $\begin{array}{l}\text { A D’x } \\
\text { küszöbvektor } \\
\text { értéke (1) }\end{array}$ & $\begin{array}{c}\text { Nem } \\
\text { megkülönböz- } \\
\text { tethető } \\
\text { fajtapárok } \\
\text { aránya GK } \\
\text { fajtáknál (\%) } \\
(2)\end{array}$ & $\begin{array}{l}\text { Nem } \\
\text { megkülönböz- } \\
\text { tethetố fajták } \\
\text { száma GK } \\
\text { fajtáknál (db) } \\
\qquad(3)\end{array}$ & $\begin{array}{c}\text { Nem } \\
\text { megkülönböz- } \\
\text { tethetố } \\
\text { fajtapárok } \\
\text { aránya MV } \\
\text { fajtáknál (\%) } \\
\text { (4) } \\
\end{array}$ & $\begin{array}{l}\text { Nem } \\
\text { megkülönböz- } \\
\text { tethető fajták } \\
\text { száma GK } \\
\text { fajtáknál (db) } \\
\quad(5)\end{array}$ \\
\hline 1 & 0,0 & 0 & 0,0 & 0 \\
\hline 2 & 0,0 & 0 & 0,0 & 2 \\
\hline 3 & 0,9 & 15 & 3,4 & 24 \\
\hline 4 & 7,5 & 43 & 11,7 & 43 \\
\hline 5 & 22,8 & 47 & 37,8 & 49 \\
\hline 6 & 46,3 & 49 & 58,3 & 49 \\
\hline 7 & 72,0 & 50 & 76,9 & 50 \\
\hline
\end{tabular}

Table 3. Number and proportion of non-distinct pairs at GK and MV wheat varieties in case of D' $x=1-7$ threshold vector. (1) Value of D'x threshold vector, (2) Proportion of non-distinct GK variety pairs, (\%), (3) Number of non-distinct GK variety pairs (pcs), (4) Proportion of non-distinct MV variety pairs (\%), (5) Number of non-distinct MV variety pairs (pcs).

A táblázat eredménye jól visszatükrözi azt a gyakorlati alkalmazást, mely szerint a D'x = 3 küszöbvektor tekinthető az ôszi búza megkülönböztethetôség megállapításához optimális értéknek. A D'x = 3 küszöbvektor szintje alatt nehéz NMF-t találni, D’x = 3 érték felett pedig a nem megkülönböztethetô fajták száma kezelhetetlen kísérleti szempontból. Korábbi megállapításunk, mely szerint a D’x vektort alkotó küszöbértékek megválasztása nagyban meghatá- 
rozza a NMF számát ebben az esetben is igazolást nyert (Harangozó et al. 2007). Az MV fajták esetében a D'x küszöbvektor növelésével a NMF növekedési üteme gyorsabbnak bizonyult. Ennek magyarázata, hogy az 50 vizsgált MV fajta összességében egymáshoz hasonlóbb volt a másik fajtakörhöz képest. Ezt a tényt alátámasztja két számítás is. A vizsgált 20 tulajdonságnál a tényleges kifejezôdési fokozat tartomány értékek összegét az MV fajtáknál kisebbnek találtuk. Az alkalmazott számítási módszer:

20

MV fajták esetén: $\sum \mathrm{x}_{\mathrm{i}}=113$

$\mathrm{i}=1$

20

GK fajták esetén: $\sum \mathrm{x}_{\mathrm{i}}=122$, ahol $\mathrm{x}_{\mathrm{i}}=\mathrm{x}_{\mathrm{i} \max }-\mathrm{x}_{\mathrm{i} \min }$. $\mathrm{i}=1$

Az $x_{\mathrm{i}}$ érték az i-edik tulajdonság kifejeződési fokozat intervallum értékét jelenti, ami az adott tulajdonságnál az 50 fajta alapján a legnagyobb $\left(\mathrm{x}_{\mathrm{i} \text { max }}\right)$ és a legkisebb $\left(\mathrm{x}_{\mathrm{i} \text { min }}\right)$ kifejeződési fokozat érték különbségét jelentette.

A másik számítás szerint az MV fajtáknál a 20 tulajdonság szórásának átlaga kisebb volt.

$$
\mathrm{S}_{\mathrm{Mv}}=1,186 \quad \mathrm{~S}_{\mathrm{Gk}}=1,285 .
$$

A NMF arányát a D'x függvényében ábrázolva látható, hogy a két görbe hasonló lefutást mutat, amit a két függvény értékeinek korrelációja $(r=0,986)$ is megerósít (1. ábra). Eredményeinket értékelve megállapítható, hogy a D’x küszöbvektor növelése esetén a NMF számának alakulása szempontjából a két vizsgált adatállomány közel azonos módon viselkedett. A függvény alakja igazolja Garzó et al. (1997) megállapítását, mely szerint a küszöbértékek növelése a megkülönböztethetó fajtapárok számát csökkenti, a nem megkülönböztethetốek számát pedig növeli. A homogén küszöbvektorok alkalmazásának jelentôsége, hogy bármely vizsgált fajnál általános képet kaphatunk a NMF számának várható alakulásáról az összes vizsgált tulajdonságot együtt kezelve.

Heterogén D’x küszöbvektorok vizsgálata a küszöbértékek kumulatív növelésével

A homogén küszöbvektorok alkalmazása a megkülönböztethetôség megállapításához nyújtott segítséget. A heterogén küszöbvektor alkalmazásával DUS tulajdonságokat egyedileg tudtuk vizsgálni. Elôször a D'x $=3$ homogén vektor D'x = 4-be alakulását elemeztük a d'x értékek kumulatív növelésével. A kumulatív növelés azt jelentette, hogy a D’x $=3$ kiindulási küszöbvektort alkotó $20 \mathrm{db}$ 
d'x küszöbértéket egyesével növeltük. Így a D’x = 3-as szintrôl a 20 küszöbvektor alkalmazásával eljutottunk a D'x $=4$ szintig, és minden egyes köztes küszöbvektor kombináció esetén meghatároztuk a hozzá tartozó NMF számot. Eredményül azt kaptuk, hogy az MV fajtáknál 1 db d'x = 4 küszöbértékhez tartozó 42 db NMF-tól eljutottunk a 20 db d'x = 4 küszöbértéket tartalmazó homogén vektorhoz tartozó 144 db NMF-ig. Ugyanezt a GK fajták esetében is kiszámítva 14 db NMF-tól 92 db NMF-ig jutottunk. A NMF arányát tulajdonságonként ábrázolva látható, hogy a két görbe közel párhuzamosan egymás alatt fut (2. ábra).

\section{1. ábra. A NMF aránya a D’x homogén küszöbvektor függvényében GK fajták} és MV fajták esetén

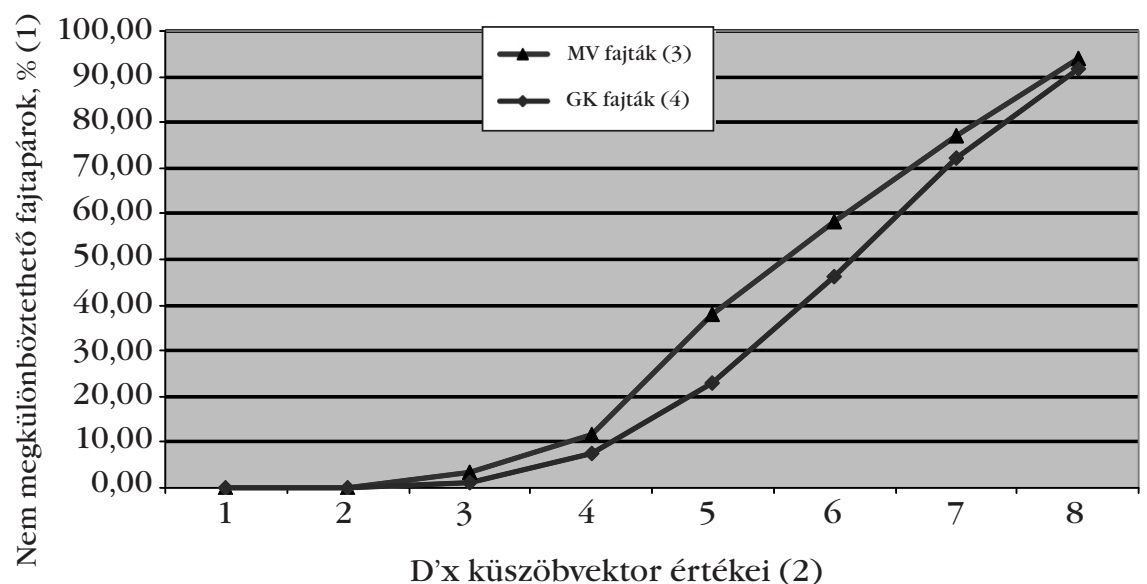

Figure 1. Proportion of non distinct pairs in the function of D' $\mathrm{x}=1-8$ threshold vector at GK and MV wheat varieties. (1) Value of D'x threshold vector (\%), (2) Proportion of non distinct pairs, (3) MV varieties, (4) GK varieties.

Ha a NMF változást úgy ábrázoltuk, hogy a NMF változást az adott tulajdonságot megelőző tulajdonsághoz viszonyítottuk, akkor még jobban látható, hogy mely tulajdonságoknál jelentett a d'x érték növelése kiugró NMF \% változást (3. ábra). A GK fajtáknál a 4., 7., 14., 15., 17. és 20. sorszámú tulajdonságoknál volt 8 db feletti, az MV fajtáknál pedig a 7., 8., 13., 16., 17. és 20. sorszámú tulajdonságoknál volt 6 db feletti NMF szám változás. A 4. kalászolás ideje, a 7. kalász viaszossága és a 20. szem fenolos elszínezôdése tehát olyan DUS tulajdonságok, amelyeknél a küszöbérték megválasztása jelentősen befolyásolta mindkét adatállománynál a megkülönböztethetőséget. 
2. ábra. NMF száma d'x = 4 küszöbérték kumulatív alkalmazása esetén a GK és MV fajtáknál

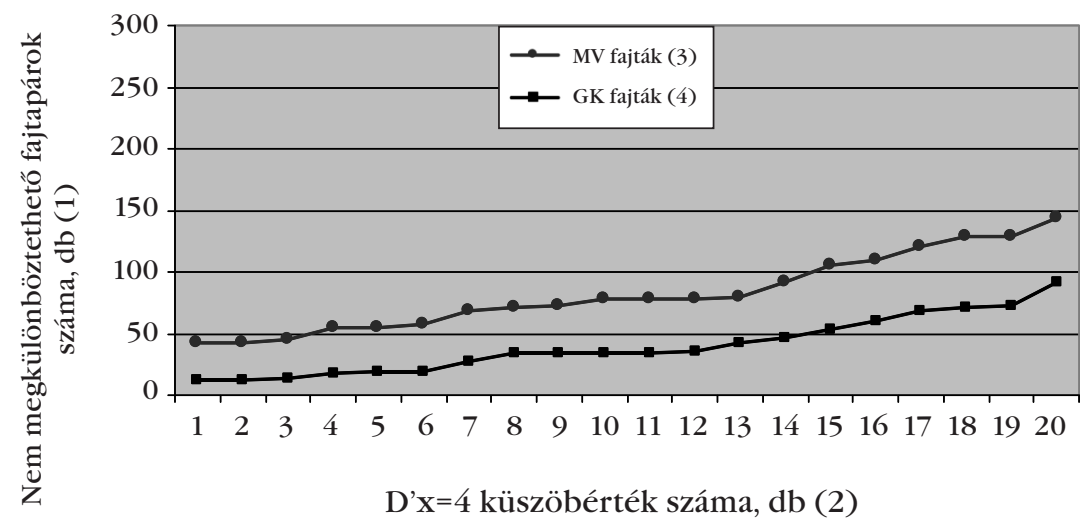

Figure 2. Number of non-distinct pairs by the cumulative application of D'x $=4$ threshold value at GK and MV wheat varieties. (1) Nr. of D'x $=4$ threshold value (pcs), (2) Nr. of non-distinct pairs (pcs), (3) MV varieties, (4) GK varieties.

3. ábra. NMF számának változása a megelőzó tulajdonsághoz képest

$$
\text { D'x }=3-4 \text { esetén }
$$

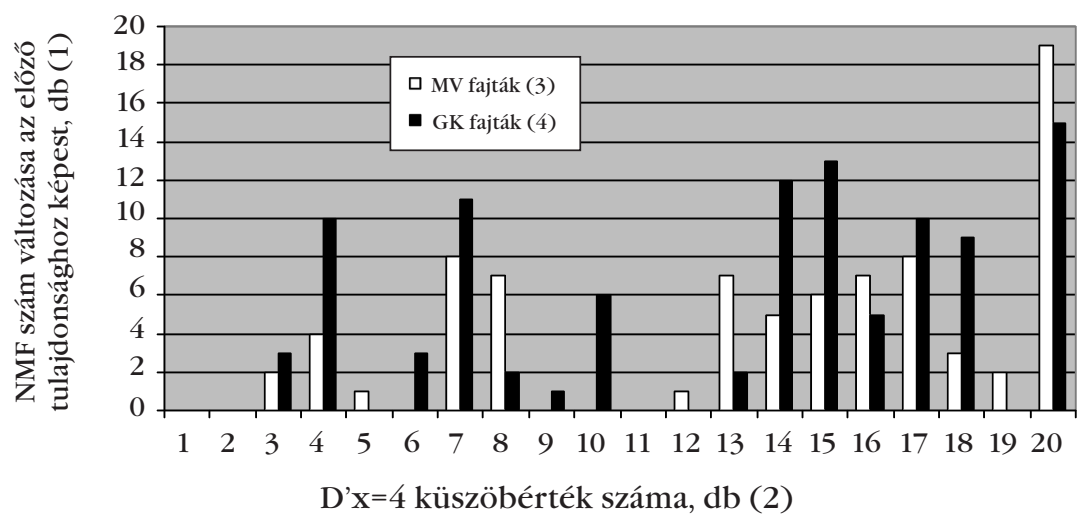

Figure 3. Change of the Nr. of non distinct pairs on the basis of preceeding value D'x = 3-4 at GK and MV wheat varieties. (1) Nr. of D'x $=4$ threshold value (pcs), (2) $\mathrm{Nr}$. of non distinct pairs on the basis of preceeding value (pcs), (3) MV varieties, (4) GK varieties. 
Heterogén D’x küszöbvektorok vizsgálata d'x küszöbérték csökkentésével és növelésével

A második esetben a kiindulási küszöbvektor 3-as értékeit minden egyes tulajdonságnál elôször 2-re, majd 4-re cseréltük. Az adott D'x küszöbvektor alkalmazásával a NMF szám alakulása jelezte, hogy a vizsgált tulajdonság miként reagált a d'x küszöbérték változtatására. A 4. és 5. ábrán tulajdonságonként láthatóak a NMF arányok. A küszöbérték növelése pozitív változást, vagyis a NMF arányának növekedését, a küszöbérték csökkentése pedig negatív változást, azaz a NMF arányának csökkenését jelentette.

A 4. ábra bemutatja, hogy az MV fajták esetén az egyes tulajdonságoknál a d'x küszöbérték növelése vagy csökkentése milyen arányban növelte a NMF számát a kiindulási D'x = 3 alapesethez képest. A d'x küszöbérték háromról négyre történt növelése 9 tulajdonságnál eredményezett NMF növekedést és 19 tulajdonságnál csökkenést. A küszöbérték csökkentésére a tulajdonságok sokkal nagyobb mértékben reagáltak, mint a küszöbérték növelésére. Érdekes, hogy a 11. kalász tömöttsége tulajdonságnál a d'x változtatása egyáltalán nem eredményezett NMF szám változást a kiindulási állapothoz képest.

\section{4. ábra. $A$ NMF változása d'x $=2$ és d'x $=4$ küszöbérték tulajdonságonkénti} alkalmazása esetén MV fajtáknál a d’x = 3 állapothoz képest

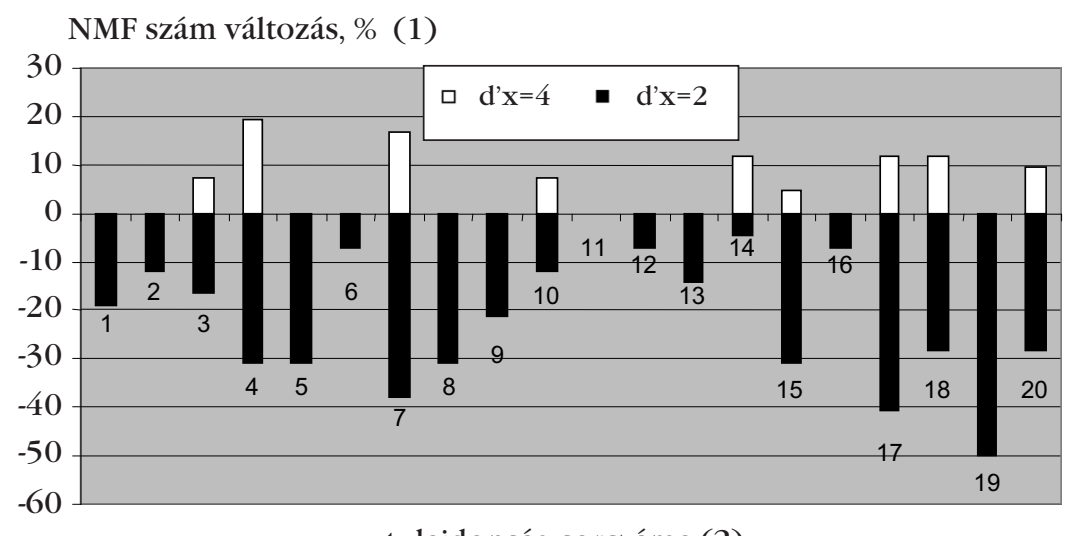

tulajdonság sorszáma (2)

Figure 4. Increase of of non-distinct pairs at d'x $=4$ and decrease of non-distinct pairs at $d^{\prime} x=2$ compared to $d^{\prime} x=3$ in MV wheat varieties. (1) Change in the $n r$. of non distinct pairs (\%), (2) Nr. of characteristic. 
Az 5. ábrán a GK fajtáknál 11db tulajdonságnál tapasztalható NMF arány növekedés, és $20 d b$ tulajdonságnál NMF csökkenés a d'x $=4$ illetve d'x $=2$ alkalmazása esetén (5. ábra).

\section{5. ábra. $A$ NMF eltérés d'x $=2$ és d'x $=4$ tulajdonságonkénti alkalmazása} esetén a D'x $=3$ vektorhoz képest GK fajtáknál

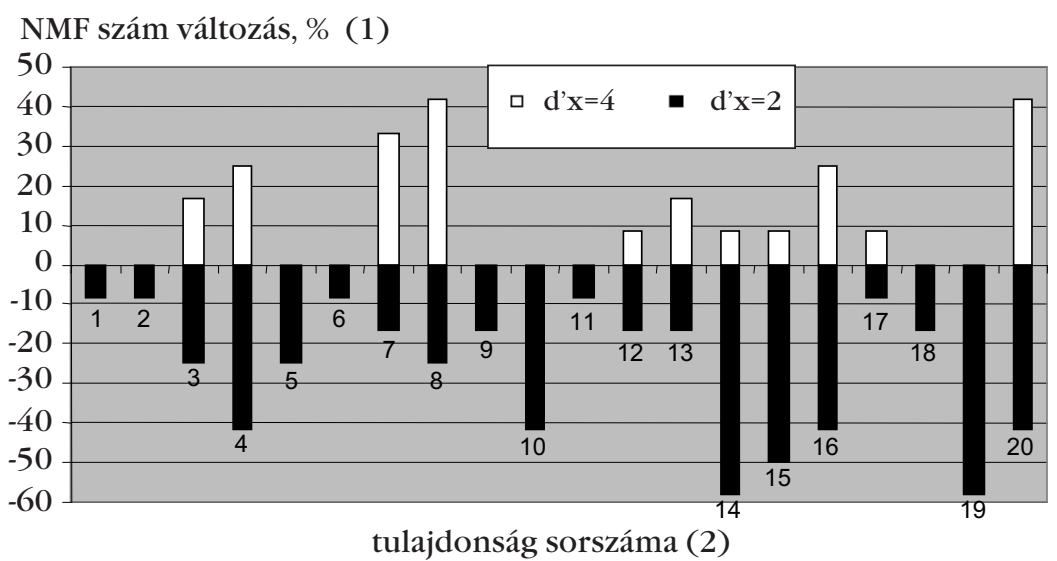

Figure 5. Increase of of non-distinct pairs at d'x $=4$ and decrease of non-distinct pairs at d' $x=2$ compared to $d^{\prime} x=3$ in GK wheat varieties. (1) Change in the nr. of non distinct pairs (\%), (2) Nr. of characteristics.

A két adatállomány összevetése alapján a következő általános megállapításokat tehetjük:

- A küszöbérték növelése egyik adatállomány esetén sem eredményezett egyértelmú és általános NMF növekedést.

- A küszöbérték csökkentése az MV fajták 11. sorszámú tulajdonságát leszámítva minden esetben változást eredményezett a NMF számában.

- A küszöbérték csökkentésre a NMF szám két tulajdonság kivételével nagyobb mértékben változott, mint annak növelésére.

- A GK fajták esetében a NMF arányának változása nagyobb mértékú.

Az egyes tulajdonságokat külön-külön tekintve néhány hasonlóság és különbség megfigyelhetô a két fajtakör között. A 4. kalászolás ideje, 7. kalász viaszossága, 19. kalászkapelyva belsô szôrözöttsége és 20. szem fenolos elszíneződése tulajdonságok bizonyultak a küszöbérték változtatásra legérzékenyebbnek. Mivel a d'x küszöbérték a fajták páros összehasonlításában a kifejezôdési fokozatok közötti különbségen alapul, ezért ahol a küszöbérték változtatása, vagyis 
a kifejeződési fokozatok különbségének nagysága jelentősen befolyásolhatja a megkülönböztethetőséget, ott a kifejeződési fokozat megállapítása nagy jelentôséggel bír. Az 1. csíra antociánossága, 2. növekedési típus, 6. levéllemez viaszossága és 11. kalász tömöttsége tulajdonságok az előzóekkel ellentétben elég stabilnak mutatkoztak. Az általunk alkalmazott módszer segítségével a két fajtakör közötti DUS tulajdonságban rejlő különbség feltárására is lehetôség adódott. A legszembetûnőbb különbségek a 8. kalásztartó szártag viaszossága, 10. szalmaszár bélvastagsága, 14. legfelső orsótag konvex oldal szôrözöttsége, 16. kalászkapelyva váll alakja és 18. kalászkapelyva fog alakja tulajdonságok között mutatkoztak.

A két fajtakör 20-20 tulajdonsága a változtatásra való érzékenység alapján az alábbi típusok szerint csoportosítható:

a) egyáltalán nem érzékeny,

b) csak csökkentésre érzékeny,

c) mindkettôre érzékeny, de a csökkentésre jobban,

d) mindkettőre érzékeny, de a növelésre jobban,

e) mindkettőre erôsen érzékeny.

Eredményeink bizonyítják, hogy a DUS tulajdonságok viselkedése jól tanulmányozhatók a küszöbértékek változtatásával. Számításaink egyértelmúen bizonyítják, hogy a fajtakísérletek kiértékelése során jelentős segítséget nyújthat a jól meghatározott küszöbvektor alkalmazása. Szükségesnek tartjuk a továbbiakban a küszöbérték csökkentése vagy növelése által bekövetkezô, megkülönböztethetőséget érintô változások vizsgálatát más nemesítési szempontból jelentős fajoknál is.

A küszöbvektor értékeinek változtatásával kapott különböző megkülönböztethetôségi százalékokat felhasználva - korábbi és a párhuzamosan folyó munkákra alapozva - e munka folytatásaként négyzetes kontingenciák chi²-próbái segítségével fogjuk meghatározni a különböző küszöbvektorok közti lényeges különbséget.

\section{IRODALOM}

CPVO TPO03/4.: 2008. Protocol for Distinctness. Uniformity and Stability Tests. Wheat. www.cpvo.eu

Csapó J.-Veress Z.: 1997. A napraforgó DUS vizsgálata, a nyári vizsgálati szakasz értékelése. Növénytermelés. 46. 1: 85-91.

Garzó L.-Barcs L. -Veress Z.: 1997. Néhány szántóföldi növény DUS-vizsgálata, a vizsgálatokban szereplő tulajdonságok típusokba osztása (őszi búza, ôszi árpa, cirok). Növénytermelés. 46. 6: 631-642. 
Harangozó T.-Veress Z.-Heszky L.: 2007. Hasonlóság és megkülönböztethetőség összefüggései a növényfajták DUS vizsgálatában. Növénytermelés 56. 5-6: 279-286.

Lázár L.-Puskás Á-Veress Z.: 1998. A kukorica DUS-vizsgálata és jellemzó tulajdonságai. Növénytermelés. 47. 1: 25-32.

Veress Z.: 1999. Hasonlósági csoportok a fajtaazonosítási vizsgálatokban. Növénytermelés. 48. 5: 271-283.

Veress Z.-Lázár L.: 1997. A DUS vizsgálatokban szereplő tulajdonságtípusok vizsgálata a megkülönböztethetôségi százalék módszerével, kukorica adatokkal. Növénytermelés. 46. 4: 401-411.

Országos Mezôgazdasági Minôsító Intézet: 1996. A búza, durum búza és árpa DUS vizsgálati módszere. Budapest. Ốszi búza. I. melléklet. 6-9.

UPOV: 2002. Az új növényfajták oltalmára létesült Nemzetközi Egyezmény Genfben. 1991. március 19-én felülvizsgált szövegének kihirdetésérôl szóló 2002. évi LI. Törvény 7. §.

UPOV: 2002. General Introduction to the Examination of Distinctness, Uniformity and Stability and the Development of Harmonized Descriptions of New Varieties of Plants, Document TGP/9. 27.

UPOV: 2003. GAIA software: Crop Expert Phenotypic Distances Between Varieties. Document TWC 21/4.

A szerzők levelezési címe - Address of the authors:

Harangozó Tamás-Veress Zoltán

Mezőgazdasági Szakigazgatási Hivatal Központ

Budapest

Keleti Károly u. 24.

H-1024 